\title{
Chrystologia biblijna - pogańskie litery. Na przykładzie chrześcijańskiego centonu „De Verbi Incarnatione”
}

\author{
Mariusz Krzysztof Piątek \\ Uniwersytet Papieski Jana Pawła II w Krakowie \\ mariuszpiatek77@gmail.com (Dttps://orcid.org/0000-0002-6382-0829
}

Starożytna kultura, nie tylko grecka i rzymska, za pomocą bogactwa swej spuścizny znajdowała aprobatę, uznanie i była z jej osiągnięciami wykorzystywana w czasach późniejszych również przez chrześcijan. Miejsca, w których dochodziło do spotkania dwóch światów - pogańskiego i chrześcijańskiego - to na przykład literatura, filozofia czy retoryka. Chrześcijanie szeroko wykorzystywali dorobek swoich poprzedników. Kształcili się przecież w pogańskich szkołach retorycznych, przyswajali greckie systemy filozoficzne i zaczytywali się w tamtejszej literaturze. Tak jak retorykę i filozofię wyznawcy Chrystusa w jakimś stopniu przynajmniej wykorzystywali do swoich celów, tak w pewnym momencie swoją uwagę zwrócili na starożytne teksty.

W ten sposób zrodziły się centony chrześcijańskie. Utwory, których autorzy wykorzystywali wersety dzieł pogańskich do wyrażania treści chrześcijańskich. Nadając przy tym nowe znaczenia zapożyczonym słowom, jak i osadzając je w nowym kontekście, lub po prostu go przejmując. Przykładem tego są centony wergiliańskie, których łącznie do naszych czasów ostało się 16, a 4 z nich można nazwać chrześcijańskimi ${ }^{1}$. Nasze rozważania nad chrystologią biblijną ograniczamy jedynie do centonu De Verbi Incarnatione. Jest to anonimowe dzieło liczące 111 wersów heksametru² ${ }^{2}$ którego czasy powstania trudno dokładnie sprecyzować ${ }^{3}$. Utwór określić można mianem bogatego teologicznie. Znajdziemy w nim bowiem treści chrystologiczne, mariologiczne ${ }^{4}$,

1 S. McGill, Virgil Recomposed. The Mythological and Secular Centos in Antiquity, Oxford 2005, s. XV.

2 J. M. Ziółkowski, M. C. J. Putnam, The Virgilian Tradition. The First Fifteen Hundred Years, New Haven 2008, s. 481.

3 Rozpiętość czasowa jest dosyć duża. Wszystkie zachowane centony wergiliańskie powstały 200-534 n.e. Por. S. McGill, Virgil Recomposed..., dz. cyt., s. XV.

4 Na temat mariologii w centonie De Verbi Incarnatione por. M. Gilski, Mariologia centonów, Wydawnictwo Scriptum, Kraków 2015, s. 195-208. 
protologiczne, hamartiologiczne i eschatologiczne. Podstawą naszej analizy będą wydania krytyczne dzieł Wergiliusza: Eneida ${ }^{5}$, Bukoliki ${ }^{6}$ i Georgiki ${ }^{7}$ oraz rzecz jasna tekst centonu w wersji łacińskiej ${ }^{8}$.

Celem artykułu jest prezentacja biblijnej chrystologii ukazanej w centonie, określenie sposobu inspiracji centonisty i zwrócenie uwagi na warstwy leksykalne tekstów, przy tym wyeksponowanie analogii i różnic wykorzystanych przez centonistę do stworzenia swojego utworu.

\section{Dzień narodzenia - dzień błogosławiony - Łk 2, 7}

Pierwszym fragmentem, który zostanie poddany analizie, będzie fragment $D e$ Verbi Incarnatione, 46-51. Centonista wykorzystał do jego zbudowania 6 wersetów pochodzących z Bukolik Wergiliusza (3 razy korzysta z tego samego wersetu, mianowicie E. VIII, 17) i 1 fragment pochodzący z Eneidy.

\footnotetext{
nascere praeque diem veniens age, lucifer, almum,

nascere, quo toto surgat gens aurea mundo,

unde etiam magnus caelorum nascitur ordo:

nascere, ut incipiant magni procedere menses,

ne maneant terris priscae vestigia fraudis,

prospera venturo laetentur ut omnia saeclo ${ }^{9}$.
}

Zacytowany fragment w swej treści odwołuje się do wyczekiwanego dnia narodzin Zbawiciela. Przedstawia dwa ważne i interesujące stwierdzenia nawiązujące do chrystologii. Oba te fragmenty skupiają się na skutkach cudownych narodzin. Pierwszym z nich ma być nastanie na ziemi gentis aurae (w. 46-47), a drugim - zniszczenie śladów dawnych zbrodni przynoszące pomyślność (w. 50-51).

5 Virgile, Énéide, Les Belles Lettres, t. 1: Livres I-IV, Paris 1977; Virgile, Énéide, Les Belles Lettres, t. 2: Livres V-VIII, Paris 1993; Virgile, Énéide, Les Belles Lettres, t. 3: Livres IX-XII, Paris 1987.

6 Virgile, Bucoliques, Les Belles Lettres, Paris 1992.

7 Virgile, Géorgiques, Les Belles Lettres, Paris 1995.

8 Poetae Christiani Minores, pars 1, Vindobonae 1888, s. 615-620 (Corpus Scriptorum Ecclesiasticorum Latinorum, 16).

9 Poetae Christiani Minores, dz. cyt., s. 618. 
Fragment pierwszy (ww. 46-47) powstał on na bazie E. VIII, 17 i E. IV, 9, centonista dwukrotnie wykorzystuje pierwszy z wymienionych tutaj wersów. Werset z Bukoliki, 8 to kwestia wypowiadana przez pasterza Damona. Poprzedza ją opis krajobrazu bukolicznego (świtanie, pastwisko, pasterz wsparty na kiju). Jest to rozpoczęcie jego pieśni, w której skarży się na los porzuconego przez ukochaną. Centonista wykorzystuje w pełni werset E. VIII, 17 na płaszczyźnie leksykalnej. Oczywistym jest, że w swoim utworze nadaje słowom Wergiliusza zupełnie inne znaczenie.

Przy rozważaniach o chrystologii już samo nawiązanie (chwilowo pomijamy to, do czego wykorzystany werset się odnosi) do Bukoliki 4 może prowadzić do niepopartych faktami skojarzeń. Bukolika 4 o tyle jest utworem enigmatycznym, o ile nie precyzuje wprost, do kogo miałaby się odnosić. W utworze tym poeta nawiązuje do dziecięcia, którego przyjście na świat miało zapoczątkować gentem auream. Miałby on zstąpić z nieba na ziemię, zapoczątkować złoty wiek, oczyścić świat ze zbrodni i występków, by potem zostać wziętym do nieba. Pośród wielu dociekań i interpretacji utworu pojawiła się również ta chrześcijańska. Za sprawą św. Augustyna z biegiem czasu zaczęto dostrzegać w tajemniczym dziecięciu Chrystusa ${ }^{10}$.

Centonista wykorzystuje motyw swego rodzaju naprawy świata i w swoim utworze odnosi go bezpośrednio do Zbawiciela. Złoty wiek w tej chrześcijańskiej wizji nastaje za sprawą przyjścia Logosu na ziemię, zwycięstwa nad grzechem i śmiercią oraz odkupienia każdego z ludzi.

Drugi fragment (w. 50-51) powstał na bazie trzech wersetów z Bukoliki 4 Wergiliusza, a mianowicie 13, 31 i 52. Wers 13 w swej treści wpisuje się w profetyczną wizję i przedstawia jeden ze skutków nadejścia cudownego dziecięcia, którego narodziny miałyby wygnać ze świata wszelkie zbrodnie (vestigia sceleris). Werset 31 nawiązuje do dawnych błędów, których skutki będą wciąż pozostawały na ziemi jeszcze przez jakiś czas do momentu wejścia w dorosłość dziecięcia. Do tego czasu pozostaną trudy pracy i wojny. Wtedy dopiero złoty wiek zajaśnieje w pełni ${ }^{11}$. Z kolei w. 52 przedstawia radość, która ma nadejść.

Jutrzenka opisywana w wersetach 46-51, jak już wspomnieliśmy, miałaby zapoczątkować na ziemi nastanie złotego wieku. Związane jest z tym bezpośrednio zniszczenie śladów dawnych zbrodni (ut ne maneant terris priscae vestigia fraudis) i nastanie pomyślności (w. 50-51). Zbrodnie, o których mowa

10 M. Cytowska, H. Szelest, Literatura Rzymska. Okres Augustowski, PWN, Warszawa 1990, s. 76-77. 11 S. Stabryła, Wergiliusz. Świat poetycki, Zakład Narodowy im. Ossolińskich, Wrocław 1983, s. 84-85. 
powyżej, to rzecz jasna w naszym centonie grzech, ale nie w ujęciu indywidualnym i konkretnym (śladem nie jest grzech pierwszych rodziców), ale powszechnym i jednostkowym (grzechy ludzkości). Jutrzenka ma nadejść, aby położyć kres tym grzechom. Przyjście Chrystusa na ziemię zgładzi występki. Zauważamy, że centonista, wybierając takie, a nie inne fragmenty w znacznym stopniu posłużył się warstwą leksykalną utworu Wergiliusza (mało dodatków własnych), przy tym ciekawym wydaje się również duża zgodność i podobieństwo na płaszczyźnie sensu i znaczenia. Wszystko to za sprawą niejednoznaczności i swego rodzaju uniwersalności wynikających bezpośrednio z Bukoliki 4.

\section{Dzień śmierci i dzień zbawienia - Rdz 3,6}

Drugim fragmentem analizowanego centonu są wersety od 63 do 65. Centonita do zbudowania tego fragmentu wykorzystał 5 różnych fragmentów pochodzących z Eneidy Wegiliusza.

Ille dies primus leti primusque salutis

monstrat iter vobis ad eum. Quem semper acerbum,

semper honoratum cuncti celebrate fauentes ${ }^{12}$.

Motywem przewodnim tego fragmentu również jest dzień. Tym razem jednak nie chodzi o dzień narodzenia Jezusa, a ten dzień, który go, nie bezpośrednio, ale jednak, poprzedził. Mamy tutaj na myśli dzień grzechu pierwszych rodziców.

W 4 księdze Eneidy werset, którym zainspirował się centonista, tj. werset 169 przybiera następująca postać: „Ille dies primus leti primusque malorum”13. Posłużył on do stworzenia 63 wersetu De Verbi Incarnatione. Już pierwsze spojrzenie na obydwa fragmenty pozwala dostrzec różnicę w użyciu jednego ze słów. Centonista w swoim utworze zamienił wergiliuszowe malorum na salutis. Za sprawą tego zabiegu zmienia znacząco przekaz wersetu Wergiliusza.

Wers 169 z 4 księgi historii Eneasza nawiązuje do romansu tytułowego bohatera z Dydoną. Królowa Kartaginy po pojawieniu się Eneasza szybko się w nim zakochuje. Omawiany werset osadzony jest w kontekście konsumpcji

12 Poetae Christiani Minores, dz. cyt., s. 618.

13 Virgile, Énéide, dz. cyt., s. 116. 
ich związku w jednej z jaskiń. Dla królowej „Ten dzień pierwszym dniem zguby był i ciężkiej troski” ${ }^{14}$. Wszystko to za sprawą późniejszych wydarzeń. Eneasz poganiany przez Merkurego podejmuje decyzje o opuszczeniu Kartaginy i zakończeniu relacji z Dydoną, która w wielkiej rozpaczy popełnia samobójstwo, nie mogąc znieść rozstania z ukochanym.

W omawianym centonie, jak już wspomnieliśmy wyżej, autor odnosi te słowa do dnia upadku pierwszych ludzi. Jednak nie jest on dla ludzi taki sam jak dla Dydony ten, w którym chroniła się przed burzą w jaskini wraz z Eneaszem. Jest to dzień, który człowiekowi przynosi podwójny skutek. Z jednej strony jarzmo grzechu, a z drugiej zbawienie. Centonista w swoim utworze w sposób bezpośredni łączy ze sobą fakt zaistnienia grzechu i przyjścia Zbawiciela. To pozwala mu nazywać dzień grzechu pierwszych rodziców jednocześnie dniem śmierci (letum) i ocalenia (salus). Takie zestawienie prowadzić może do wniosku jakoby autor De Verbi Incarnatione wyznawał pogląd, że wcielenie Syna Bożego nie wydarzyłoby się, gdyby wcześniej nie wydarzył się grzech Adama i Ewy.

W przypadku wersetów 64 i 65 omawianego centonu, które powstały z połączenia En. II, 388, En. V, 49, En. V, 50 i En. VIII, 173, inspiracja z księgi II (monstrat iter) jest typowo literalną i nie ma większego znaczenia. Podobnie sprawa się ma z En. VIII, 173, gdzie nie możemy dopatrywać się niczego poza wykorzystaniem słów autora Eneidy.

Inaczej może być z En. V, 49-50, w którym możemy dostrzec nieco większe podobieństwo do analizowanego utworu. We fragmencie tym Eneasz w przemowie do rodaków nawiązuje do śmierci swojego ojca. Sięga pamięcią do tego dnia, który będzie dla niego zawsze smutnym (acerbus) i drogim (honoratus) ${ }^{15}$. Syn Anchizesa gwarantuje, że w każdym miejscu i w każdych warunkach będzie spełniał ofiary, by uczcić ojca. Wyraża również radość z zaistniałych okoliczności. Dziękuje bogom za to, że pozwalają mu w pierwszą rocznicę śmierci ojca odwiedzić jego grób.

Centonista oprócz warstwy leksykalnej tego fragmentu wykorzystuje również jego kontekst. Zręcznie wpisuje w swoje rozważania na temat dnia popełnienia występku przez pierwszych rodziców ambiwalencję ukazaną przez Eneasza co do dnia śmierci jego ojca.

14 Publiusz Wergiliusz Maro, Eneida, przekł. T. Karyłowski, oprac. S. Stabryła, Zakład narodowy im. Ossolińskich, Wrocław 1980, s. 103.

15 Publiusz Wergiliusz Maro, Eneida, dz. cyt., s. 124. 


\section{Współistotność syna - J 10, 30}

Kolejnym fragmentem centonu, który zostanie poddany analizie, jest fragment De Verbi Incarnatione, 35-40. Autor do jego ułożenia wykorzystał 9 fragmentów pochodzących z Eneidy i 1 z Georgik Wergiliusza.

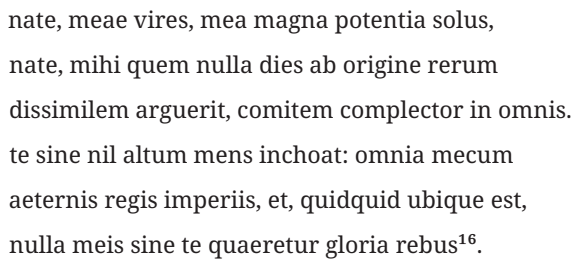

Pierwszym wersem, na który chcemy zwrócić uwagę, jest En. I, 664 (De Verbi Incarnatione, 35). W utworze Wergiliusza kwestię tę wypowiada bogini Wenus do swojego syna Kupidyna. Jej słowa osadzone są w kontekście realizacji przez nią jej zamiarów względem Eneasza i Dydony. Celem bogini było doprowadzenie do tego, aby królowa Kartaginy zakochała się w jej synu. Do jego realizacji wykorzystuje brata Eneasza - Kupidyna, który pod postacią syna Eneasza - Askaniusza miał zbliżyć się do królowej i sprawić, by ta zapałała miłością do przywódcy uciekinierów z Troi. Słowa, które nas tu interesują, inicjują wypowiedź matki do syna: „nate, meae vires, mea magna potentia, solus"17. Zauważamy przy tym całkowite przejęcie wersu przez centonistę. Od razu nasuwa się porównanie bogini Wenus do Boga Ojca, którzy zwracają się do swoich „dzieci” w słowach wyrażających ich wzajemny bliski związek. Jednak w przypadku centonu słowa kierowane przez Ojca do Syna mają zupełnie inny cel, niż wypowiedziane przez Wenus do Kupidyna. Informacji o tym dostarczają nam kolejne wersety utworu:

nate, mihi quem nulla dies ab origine rerum dissimilem arguerit, comitem complector in omnis.

Za sprawą zacytowanych wyżej wersetów odkrywamy prawdę o współistotności Ojca z Synem, która wyraża się nie tylko w braku inności (nate, quem

16 Poetae Christiani Minores, dz. cyt., s. 617.

17 Virgile, Énéide, dz. cyt., s. 31. 
nulla dies dissimilem arguerit), lecz również we współrządzeniu wszystkim (comitem complector in omnis).

De Verbi Incarnatione, 38 cechuje się swego rodzaju wyjątkowością. Wszystko to za sprawą inspiracji pochodzącej z Georgik Wergiliusza, który w początkowym fragmencie III księgi swojego poematu rolniczego zwraca się do Mecenasa - przyjaciela i protektora ${ }^{18}$, a więc do postaci historycznej. Słowa „Te sine nil altum mens incohat” ${ }^{19}$ wyrażają, jak się wydaje, dalszy ciąg laudacji przyjaciela, podkreślając przy tym jego ogromny wpływ na samego autora, jak i jego dzieło. Zwrot ten autor centonu w swoim utworze przypisuje Bogu Ojcu, który w ten sposób zwraca się do Syna. Na gruncie centonu i w kontekście chrystologii te wergiliańskie słowa pozwalają nam jeszcze raz odkryć prawdę o współistotności Ojca i Syna.

Ostatnia część refleksji dotyczy fragmentów z IX księgi Eneidy, 277, 278, 281 i 282. Szczególnie istotne wydają się pierwsze dwa, które wypowiada Askaniusz, syn Eneasza do Euryalusa, jednego z wojowników trojańskich: „Za druha na wszelakie przygody obrałem. Bez ciebie żadnych czynów dłoń moja nie pocznie”20.

W obozie Trojan na skutek nieobecności Eneasza trwają narady. Docierają wiadomości, jakoby Turnus wraz ze swoim wojskiem szykował się do ataku. Wspólne rozmyślania doprowadzają zebranych do konkluzji i świadomości o konieczności powiadomienia o wszystkim Eneasza. Droga do syna Wenus wiedzie poprzez obóz italski, a do realizacji zadania zgłaszają się dwaj młodzieńcy - Nizus i Euryalus. W tym właśnie kontekście zacytowane wyżej słowa kieruje Askaniusz do jednego z nich. Wypowiedź tę poprzedza radość z powodu śmiałości młodych Trojan oraz zapowiedź godnego ich wynagrodzenia.

Wersety te, z racji tego, kto je wypowiada, nabierają znaczenia absolutnego. Przy okazji kolejnego potwierdzenia tej samej istoty obydwu dostrzegamy również wspólnotę działań. Ojciec nie działa bez Syna, a Syn nie działa bez Ojca.

\section{Chrystus drogą do 0jca - J 14, 6}

Ostatnim fragmentem, nad którym się pochylimy, będzie fragment De Verbi Incarnatione, 80-85. Powstał on z 9 części Eneidy:

\footnotetext{
18 S. Stabryła, Wergiliusz. Świat poetycki, dz. cyt., s. 109.

19 Virgile, Géorgiques, dz. cyt., s. 40.

20 Publiusz Wergiliusz Maro, Eneida, dz. cyt., s. 260.
} 
Mortalem eripiam formam et praemia reddam

fortunatorum nemorum sedesque beatas.

non eritis regno indecores, nec vestra feretur

fama levis mecum pariter considere regnis.

urbem, quam statuo, vestra est: intrare licebit.

nusquam abero et tutos patrio vos limite sistam ${ }^{21}$.

Pierwsze słowa cytatu (mortalem eripiam formam) padają z ust Jowisza w rozmowie z boginią Cybele. Ten niegdyś obiecał jej, że statki, którymi Eneasz dopłynie do Italii, zamienią się w nimfy. Powyższe słowa wyrażają zamiar spełnienia przez boga danej obietnicy. Po raz kolejny uwidacznia się inspiracja jedynie literalna, a nie typu kontekstualnego, bowiem w naszym centonie słowa te wypowiada sam Chrystus (zostały przejęte słowa, ale całkowicie zmieniony kontekst wypowiedzi) i wspomina w nich o sobie i o swojej postaci śmiertelnej, przez co fragment ten nabiera dużego znaczenia teologicznego. Jest to wyraz zachowania przez Chrystusa natury ludzkiej po śmierci. Nie była ona jedynie wykorzystana do spełnienia zamierzonej ziemskiej misji. Druga część pierwszego zdania (praemia reddam fortunatorum nemorum sedesque beatas) nawiązuje do VI księgi Eneidy i pobytu Eneasza w świecie podziemnym, a konkretniej rzecz ujmując, w Elizjum. Naturalny, czyli szczęśliwy obraz tej krainy zostaje wykorzystany w centonie i utożsamiony z królestwem niebieskim. Chrystus zapowiada, że przyzna nagrody i błogosławioną pozycję wśród gajów, które są szczęśliwe.

Kolejne wersety poematu 83 i 84 powstały na bazie fragmentów 572 i 573 z I księgi Eneidy. W utworze autorstwa Wergiliusza kwestię tę wypowiada Dydona, a słowa swe kieruje do przybyszów z Troi. W nich wyraża pełną życzliwość wobec Eneasza i jego towarzyszy. Pozwala im zostać w swoim królestwie i obiecuje opiekę. Miasto, którym włada, nazywa również ich miastem. Centonista, przejmując słowa królowej, umieszcza je w dalszym ciągu wypowiedzi Chrystusa, który niejako przekazuje swoje królestwo na rzecz ludzi (urbem, quam statuo, vestra est). W tym fragmencie możemy dopatrywać się również wywyższenia ludzkiej natury (mecum pariter considere regnis). 


\section{Podsumowanie}

W 111 wersetach autor centonu De Verbi Incarnatione zawarł bogatą chrystologię biblijną. Za pomocą słów i wersetów Wergiliusza przedstawia główne idee teologiczne dotyczące Chrystusa, tj. Jego narodzenie, zapowiedź zniszczenia grzechu i zaprowadzenie nowego porządku (gens aurea), współistotność Syna i Ojca oraz cel Jego odkupieńczej misji, którym było zbawienie człowieka.

Ze względu na charakter gatunku jakim, jest centon, w pracy autora poematu widoczny jest dwojaki sposób budowania wersetów. Z jednej strony mamy do czynienia z inspiracjami typu literalnego, czyli takimi, w których dla centonisty pomocą do zbudowania własnego utworu jest jedynie słowo lub werset. W tym wypadku centonista umieszcza fragmenty dzieł Wergiliusza w swoim poemacie i zmienia ich znaczenie (punkt 2). Z drugiej strony w rozważaniach chrystologicznych znajdują się i takie fragmenty, w których autor oprócz zapożyczenia warstwy literalnej utworu Wergiliusza sięga także po ich kontekst (punkt 1). Nie brakuje i takich fragmentów, w których centonista dokonuje modyfikacji wybranego przez siebie wersetu i poprzez zamianę jednego słowa uzyskuje pożądane przez niego znaczenie (punkt 2).

Dzieła Wergiliusza były dla autora De Verbi Incarnatione raczej trudnym podłożem do pracy. Świadczy o tym fakt częstego budowania wersetów w chrześcijańskim centonie z połączenia kilku Wergiliusza (często pochodzących z różnych fragmentów utworu) oraz niewielka ilość struktur dojadycznych, choć to z drugiej strony mogło być wyrazem nieco większej ambicji autora, który mógł unikać w ten sposób źle postrzeganej ówcześnie praktyki przejmowania kilku następujących po sobie wersetów z danego utworu ${ }^{22}$.

Do prezentacji chrystologii biblijnej centonista w największym stopniu posłużył się Eneida, później Bukolikami, a najmniej wykorzystał Georgiki. Brak jest jednak inspiracji konkretnymi postaciami wergiliańskimi. Nie można też odnaleźć bezpośrednich podobieństw między nimi a bohaterami centonu.

22 D. Piasecki, Centony Homeryckie. Spotkanie tradycji pogańskiej z chrześcijańską, Wydawnictwo Scriptum, Kraków 2014, s. 62. 


\section{Abstrakt}

\section{Chrystologia biblijna - pogańskie litery. Na przykładzie chrześcijańskiego centonu „De Verbi Incarnatione”}

Artykuł prezentuje chrystologię centonu De Verbi Incarnatione. Jego głównym celem jest ukazanie sposobu, w jaki centonista wykorzystuje fragmenty dzieł Wergiliusza do stworzenia chrześcijańskiej teologii w swoim poemacie. Czy używa tylko liter, a może korzysta również z kontekstu, który pojawia się na kartach Eneidy, Bukolik i Georgik. W poszukiwaniu podobieństw i różnic pomiędzy De Verbi Incarnatione a poematami Wergiliusza zostaną przeanalizowane cztery fragmenty, które prezentują biblijną chrystologię - Łk 2, 7, Rdz 3, 6, J 10, 30, J 14, 6.

Słowa kluczowe: teologia biblijna, chrystologia, centon, Wergiliusz, De Verbi Incarnatione

\section{Abstract}

\section{Biblical Christology, Pagan Letters: The Example of the Christian Cento „De Verbi Incarnatione”}

This article presents the Christology of the cento De Verbi Incarnatione. Its main aim is to present the way in which the cento's author makes use of fragments of Virgil's works to create Christian theology in his poem. Does he only use the letters, or does he also use the context that appears on the pages of the Aeneid, Eclogues, and Georgics? In order to find similarities and differences between De Verbi Incarnatione and Virgil's poems, the following four fragments that present Biblical Christology have been subject to analysis: Luke 2:7, Genesis 3:6, John 10:30, and John 14:6.

Keywords: Biblical theology, Christology, cento, Virgil, De Verbi Incarnatione

\section{References}

Cytowska, M., \& Szelest, H. (1990). Literatura rzymska. Okres augustowski. Państwowe Wydawnictwo Naukowe. Gilski, M. (2015). Mariologia centonów. Wydawnictwo Scriptum.

McGill, S. (2005). Virgil recomposed. The mythological and secular centos in antiquity. Oxford University Press.

Piasecki, D. (2014). Centony homeryckie. Spotkanie tradycji pogańskiej z chrześcijańska. Wydawnictwo Scriptum. Poetae christiani minores. (1888). Vindobonae.

Publiusz Wergiliusz Maro. (1980). Eneida (S. Stabryła, Ed.; T. Karyłowski, Trans.; 3rd ed.). Zakład Narodowy im. Ossolińskich.

Stabryła, S. (1983). Wergiliusz. Świat poetycki. Zakład Narodowy im. Ossolińskich.

Virgil. (1977). Enéide (J. Perret, Ed.; Vol. 1). Belles lettres.

Virgil. (1987). Enéide (J. Perret, Ed.; Vol. 3). Belles lettres.

Virgil. (1992). Bucoliques (E. de Saint-Denis \& R. Lesueur, Eds.; 5th ed.). Belles lettres.

Virgil. (1993). Enéide (J. Perret, Ed.; Vol. 2). Belles lettres.

Virgil. (1995). Géorgiques (R. Lesueur \& E. de Saint-Denis, Eds.; 9th ed.). Belles Lettres.

Ziolkowski, J. M., \& Putnam, M. C. J. (Eds.). (2008). The Virgilian tradition. The first fifteen hundred years. Yale University Press. 